\title{
Studies of Vascular and Other Lesions in KK Mice
}

\author{
R.A. Camerint-Davalos*, W. Oppermana, R. Mitte, and T. Ehrenketch \\ New York Medical College, New York, USA
}

Summary. Glomerulosclerosis was found in $47 \%$ of 64 nonobese genetically "diabetic" KK mice. The changes consisted of a progressive increase in mesangial matrix and cells forming diffuse lesions. Nodular-type lesions, made up of mesangial matrix and cells were also noted, and there were many so-called exudative lesions. The in cidence of these lesions increased significantly with age. Lesions of blood vessels, interstitial tissue and tubules were not significant. - Gangrene of the extremities was found thus far in $4 \mathrm{KK}$ mice. - Tolerance to oral glucose was impaired in a very high percentage of animals. Gly. cosuria was found mostly during the OGTT. In a significant percentage of animals serum fasting triglyceride values were high. Pancreatic immunoreactive insulin was about double and serum IRI three times higher in the KK mice. Elevated BUN levels and significant proteinuria were found in some of the KK. mice. $K K$

Lésions vasculaires et autres caractéristiques de la souris

Résumé. La gloméruloselérose a été trouvée chez $47 \%$ de 64 souris KK non-obèses et génétiquement diabétiques. Les altérations consistent en un épaississement progressif de la matrice mésangiale et en des cellules montrant des lésions diffuses. Des lésions du type nodulaire se composant de matrice mésangiale et de cellules ont été également observées ainsi qu'un grand nombre de lésions dites exsudatives. La fréquence de ces lésions augmente significativement avec l'âge. Les lésions des vaisseaux sanguins, du tissu interstitiel et des tubules ne sont pas significatives. - Jusqu'ici, la gangrène des extrémités n'a été observée que chez 4 souris KK. Un pourcentage très élevé d'animaux montre une tolérance au glucose diminuée. La glycosurie a été surtout observée au cours de l'épreuve orale de tolérance au glucose. Un pourcentage significatif d'animaux à jeun montre un taux élevé de triglycérides sériques. Chez la souris KK, le contenu pancréatique en insuline immunoréactive (IRI) est environ double et l'TRI sérique trois fois plus élevée. Des taux élevés d'azote uréique circulant ainsi qu'une protéinurie ont été trouvés chez quelques souris KK.

Degenerative und andere Veränderungen der KK-Maus Zusammenfassung. Die Nieren von 64 normalgewichtigen hereditär-hyperglykämischen KK-Mäusen wurden auf das Vorhandensein sogenannt ,typischer" diabetischer Veränderungen hin untersucht. In $47 \%$ der Fälle bestand eine interkapilläre Glomerulosklerose, die durch eine Verbreiterung der Basalmembranen und durch eine Zunahme der Matrix des Mesangiums gekennzeichnet war. Außerdem wurden sowohl noduläre Veränderungen des Mesangiums als auch sogenannte exsudative Läsionen festgestellt. Sämtliche Veränderungen waren bei älteren Tieren häufiger anzutreffen als bei jungen. Das spontane Auftreten von Extremitätengangrän bei bisher 4 KKMäusen wird als Zeichen für das Bestehen peripherer Gefäßveränderungen gedeutet. - Nach oraler Glucosebelastung trat bei praktisch allen Tieren Glucosurie auf und die Glucosetoleranz war bei einem großen Teil vermindert. Im Nüchternzustand war bei einem beträchtlichen Teil der untersuchten Tiere eine Erhöhung der Plasmatriglyceride festzustellen. Der Insulingehalt des Pankreas war doppelt und die Insulinkonzentration des Serums dreimal so hoch wie bei Normaltieren. Mehrere KK-Mäuse hatten erhöhte Harnstoffikonzentrationen im Blut und waren deutlich proteinurisch.

Key-words: Spontaneous diabetes, KK mouse, diffuse, nodular-type, exudative, glomerulosclerosis, genetically determined, insulin in serum, insulin in pancreas, lipids in serum, BUN in serum, hepatic fetal lipid content, weight, gangrene, microaneurisms.
We know now that diabetic patients, because they live longer, are prone to the so-called "vascular complications"; but we do not know why they develop the microangiopathy, and what factors control the severity and progression of the diabetic angiopathy. In any attempt to answer these questions, one of the main obstacles is the difficulty in finding and following a sizeable group of patients with sequential biopsies during the different stages of the disease. This makes it almost imperative to try to answer some, if not all, the questions by the study of animals with diabetes.

Unfortunately even though diabetes has been found in many animal species, it has not always been possible to prove the genetically determined character of the dysmetabolism. Kondo and his associates established many mouse strains from Japanese mated mice. This paper describes some of the studies done by our

* Supported in part by grants from N.I.H. \# AM, 13343-01, Health Research Council of City of New York and Pfizer Pharmaceutical Company. group in the genetically determined, spontaneously diabetic Japanese KK mice [4].

\section{Material and Methods}

The KK mice studied were kept under constant laboratory conditions and fed an $11 \%$ regular mouse chow diet (Old Guilford). Primarily brothers and sisters were mated at 2-6 months of age, during the last three years. Most of the KK mice were weighed weekly.

As controls, Swiss Albino mice were kept under the same laboratory conditions for several years. Breeding of this strain (brother/sister and cousin) has been carried out in the past two years over six generations.

After an $8 \mathrm{~h}$ fast, the oral glucose tolerance test (OGTT) was performed by oral intubation of $0.1 \mathrm{ml} / 10$ g body weight of a $30 \%$ glucose solution. Blood samples were obtained from the tail of the animal at $0,30,60$, 120 and $180 \mathrm{~min}$, and the blood glucose was determined by the Ferricyanide method of Hoffman in the Tech- 
nicon autoanalyzer. Blood for insulin was collected in plain micro blood collecting tubes and centrifuged for $20-30 \mathrm{~min}$ after one half hour refrigeration. Immunoreactive insulin levels were measured by our micro modification of the double antibody technique [5]. The pancreatic insulin was extracted by the acidalcohol method. The Uristick paper strip was used for determination of glucose and proteins in the urine. Blood urine nitrogen was measured by the micro method of Beale et al. Total cholesterol and triglycerides were determined by the methods of Abell $e t a l$. and Van Handel et al.

Metabolic and structural studies were carried out as much as possible at $1,2,4,6,9,12,15$ and 18 months of age. A certain number of mice were sacrificed in each age group. Complete autopsy was performed in a few animals. During the last few months open kidney biopsy was done in the $\mathrm{KK}$ and the control animals at different age groups. The tissue was cut and fixed in $10 \%$ neutral formalin. After parafin embedding, sections were cut at 3-4 microns and stained with hematoxylin and eosin (H\&E), periodic acid Schiff (PAS) and chromotrope silver methenine (CSM).

In a representative number of cases the pancreatic tissue and the eyes were evaluated. For retinal studies the trypsin digestion technique of Kuwara and Cogan and the silver nitrate technique according to Kaczurowski [1] were used. For the corneal studies after fixation with formalin or in absolute alcohol, routine and special stains for demonstration of calcium were employed.

For the study of liver content in fetuses, samples of fetal livers from $\mathrm{KK}$ and control pregnant mice obtained from the 10th to the 17th day of pregnancy, new born livers ( 0.5 to $5 \mathrm{~h}$ after delivery) and $24 \mathrm{~h}$ of life, were used. Twelve samples of liver were obtained in each gestational and new-born period selected. Methanolchloroform (2 to 1) was used for lipid extraction according to Folch method, determination by thin layer chromotography.

\section{Results}

\section{Birth and mortality rate}

The rate of still births was less than $1 \%$ for the Swiss Albino control mice, and $24 \%$ for the KK mice. Mortality rates in the first week were about 0 and $21 \%$. Weight

When male and female mean weekly weights were analyzed together, the KK mice do not show significant differences from the controls. Female KK were in general heavier than males.

\section{Biochemical abnormalities}

Tolerance to glucose. As may be seen in Fig. 1, the mean absolute blood sugar values during the oral glucose tolerance test (OGTT) were higher in the KK mice up to 12 months of age when compared with the controls. The differences were significant $(p<0.01$ to $<0.001$ ) at all the time periods (except at the fasting stage at 4 months and $180^{\prime}$ at 9 months) at $2,4,5,9$ months of age [6]. The increments from fasting blood sugar were also significant in the same age groups.

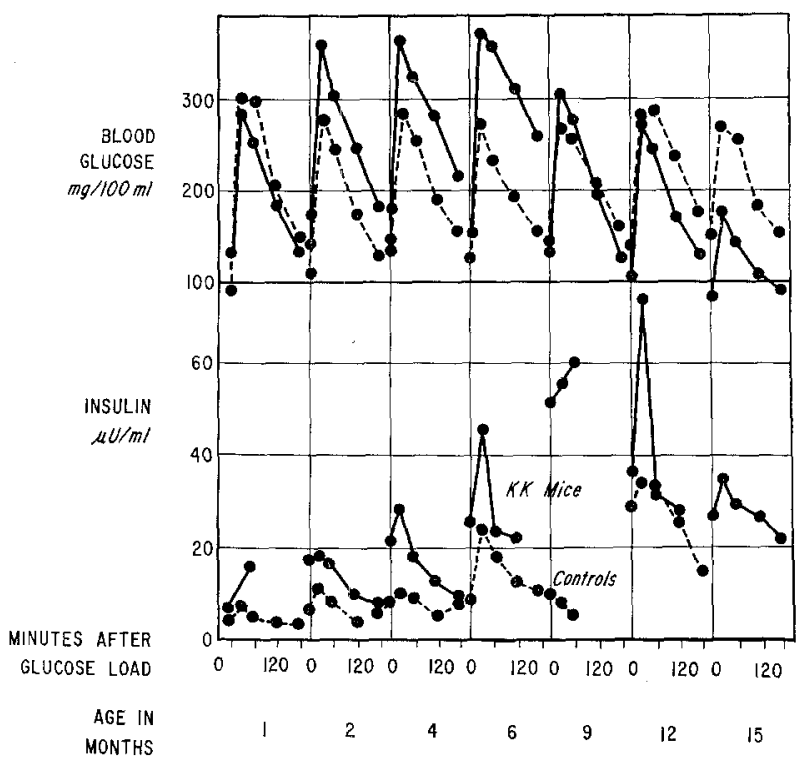

Fig. 1. Blood sugar and immunoreactive insulin during the oral glucose tolerance test. An average of $150 \mathrm{KK}$ and 100 control mice were studied in each age group

Not all the KK mice showed hyperglycemia during the life span. The frequency of hyperglycemic ${ }^{1}$ animals in different generations is shown in the Table. As may be seen, a higher percentage of hyperglycemic animals was found in generations $F 6, F 8, F 11$, and $F 12$.

Table. Percent of hyperglycemic KK mice

\begin{tabular}{lll}
\hline$F$ & 6 & $87.5 \%$ \\
$F$ & $68 \%$ \\
$F$ & 8 & $87 \%$ \\
$F$ & 9 & $56 \%$ \\
$F$ & 10 & $46 \%$ \\
$F$ & 11 & $79 \%$ \\
$F$ & 12 & $80 \%$ \\
\hline
\end{tabular}

When the effect of several hormones on the OGTT was studied in a group of normoglycemic KK mice less than 2 months old [7] it was found that they reacted differently than the controls. The KK mice maintained higher blood sugar values up to $3 \mathrm{~h}$ after glucagon injection and after pretreatment with growth hormone and triamcinolone. (Fig. 2) The response to epinephrine was delayed in the KK mice. No significant difference in the blood sugar fall after insulin was found.

Glycosuria. During the OGTT glycosuria was found frequently among the KK mice with high blood sugar

1 At least 1 blood sugar value above 1 S.D. from the mean of controls. 
values. Spontaneous glycosuria was only found occasionally.

Lipids. When lipid fractions were studied [2] in the livers of fetuses, it was found that values for KK fetuses were several fold greater for phospholipids, triglycerices, free cholesterol and cholesterol esters, at the 10th day and at delivery time with subsequent decrease.

Serum triglycerides and cholesterol were studied in $28 \mathrm{KK}$ mice and 25 controls. Higher triglyceride values were found in the KK animals. (Mean KK values 91 was about double in the KK's. Histologically, the pancreas of KK animals showed hypertrophy and hyperplasia of the islet, persisting up to 18 months.

\section{Structural abnormalities}

Glomerulosclerosis. Significant glomerulosclerosis was found in $47 \%$ of $64 \mathrm{KK}$ mice so far studied, but not in 50 Swiss Albino controls [8]. The glomerular changes consisted of a progressive increase in mesangial matrix and cells, beginning in the stalk area and
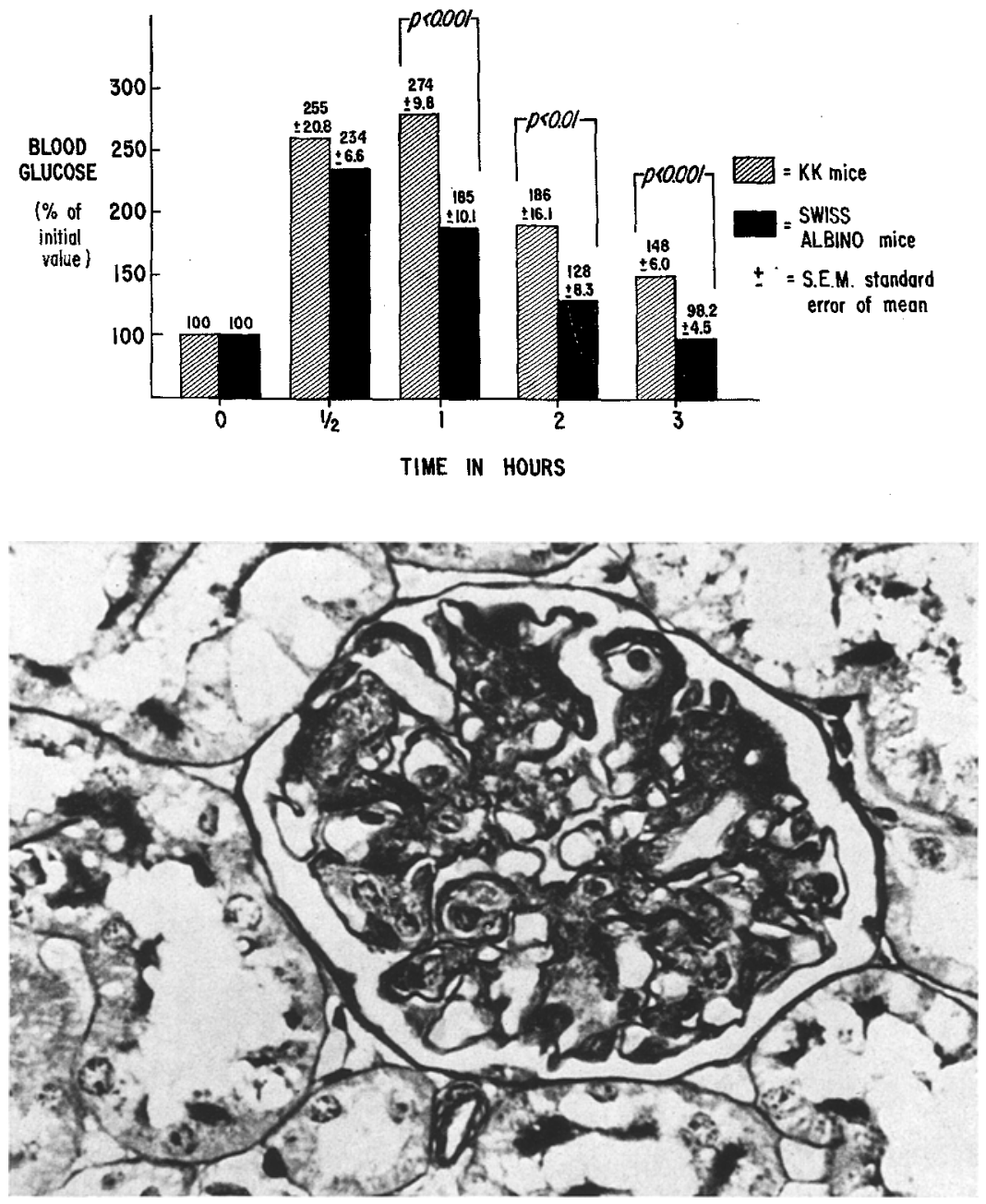

Fig. 2. Effect of triamcinolone in normoglycemic 2 month old mice. TOP. No mean blood sugar differences during OGTT between KK and control mice. BOTTOM-Significantly different mean blood sugars during OGTT after pretreatment with triamcinolone ( $2 \mathrm{mg} / \mathrm{mouse} /$ day for 3 days)
Fig. 3. Moderately severe, diffuse glomerulosclerosis, increase in mesangial matrix and cells, with widening of the mesangial space. Moderate thickening of capillary walls. 15 months old animal. PAS stain $\times 800$ $\mathrm{mg} \%$ with $63 \mathrm{mg} \%$ for the controls $-p<0.001)$. No relation with age was found. Cholesterol was in the same range in the KK and control mice.

Blood urea nitrogen. (BUN) The average BUN levels in control mice was found to be in the range between 20 to $30 \mathrm{mg} \%$. In a few KK mice, marked BUN elevations were found.

Immunoreactive insulin. (I.R.I.) Serum IRI was consistently elevated in the KK mice, with peak values at 12 months (Fig. 1) (peak blood sugar values in the OGTT at 6 months). Pancreatic extractable IRI forming diffuse lesions. (Fig. 3) In some of the animals, nodular-type lesions (Fig. 4) appear to be due to further progression of the diffuse changes, and were made up of matrix and cells resulting in a greater segmental widening of the mesangial space. Nodules made up exclusively of matrix without cells were not encountered. As a rule the nodules were located near the hilus. Exudative lesions (Fig. 5) were noted in the glomerular tuft within the capillaries. Some of the exudative lesions were very large, distending the capillary loop. The basement membrane (BM) showed 
segmental thickening of a mild to moderate degree. In some glomeruli the thickened BM was also markedly irregular forming large club-like projections on the outer surface of the capillary loop. The incidence of these lesions increased significantly with age.

Lesions of blood vessels were limited to rare hyalinization of arteries and arterioles. Changes in tubules and interstitial tissue were not significant.

In $18 \mathrm{KK}$ mice, open kidney biopsies were performed at different ages, and the structural changes cells diffusely distributed. It is expected that this new approach of serial biopsies will provide a better evaluation of the relation between the dysmetabolism and the structural changes (Fig. 6).

Corneal calcification. An oval shaped white opacity, fairly centrally located in the cornea was found on biomicroscopic examination in 187 of 190 eyes [3]. With magnification, the changes were found to consist of many polygonal plates of opacification with an intact epithelium over the lesion and vascular invasion
Fig. 4. Nodular and diffuse type of advanced glomerulosclerosis. There is compression of capillaries. Some capillary walls are thickened. 15 month-old animal PAS stain $\times 800$
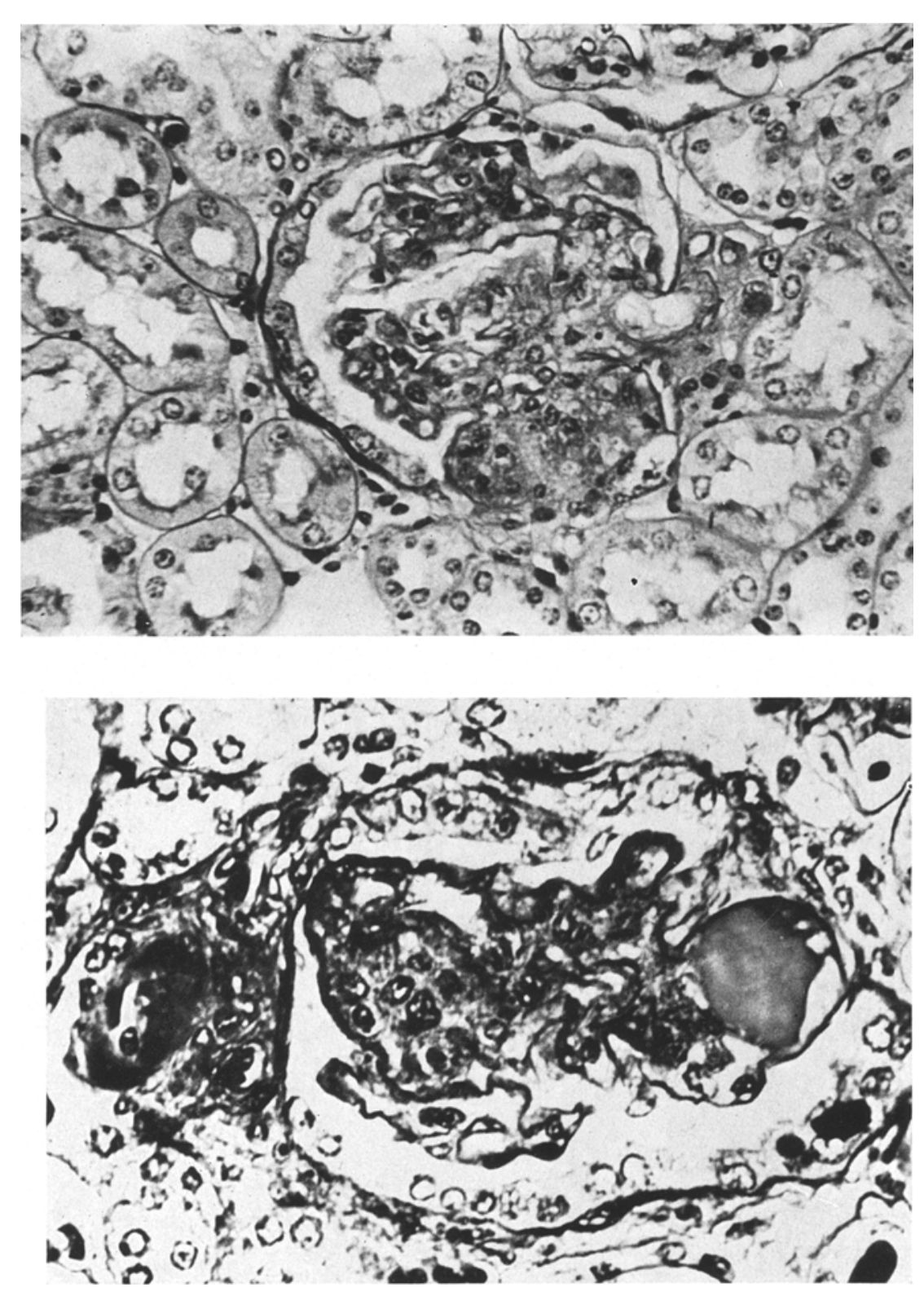

Fig. 5. Large exsudative lesion apparently distending a capillary lumen. There is moderate increase in mesangial matrix and cells and striking segmental thickening of capillary walls. An arteriole near the glomerulus, probably the afferent arteriole, shows marked thikkening of the wall with hyalinization, as well as narrowing of the lumen. 15 month old animal. P.A.S. Stain $800 x$ found were similar to the lesions described above, depending on the age of the animal. In $6 \mathrm{KK}$ mice a second biopsy was performed, 2 months after the first; in every case there was increased mesangial matrix and in many of the eyes. Biomicroscopic and histologic examination failed to reveal the presence of cataracts in many of the animals.

No correlation was found between the changes in 
the cornea and the age or sex of the animals. Severity of corneal lesions was not related to the level of hyperglycemia.

Histological examination of the tissue revealed extra cellular deposition of calcium, with infiltration of the anterior layers of the stroma with acute and chronic inflammatory cells and blood vessels. Microincineration and treatment of tissue confirmed with hydrochloric, sulfuric and acetic acids verified that the calcium deposits in question were compounds of carbonate or sion" technique, Sery and Kaczurowski (personal communication) were able to demonstrate microaneurisms in the KK mouse. With the same technique we also found in a few KK mice some microaneurisms in the retina. More work should be done to confirm this finding.

Gangrene. Three KK mice were found so far with wet gangrene of the extremities ${ }^{3}$. (igF. 7) Histological examination revealed extensive gangrenous tissue with muscle and bone involvement, with thick walled
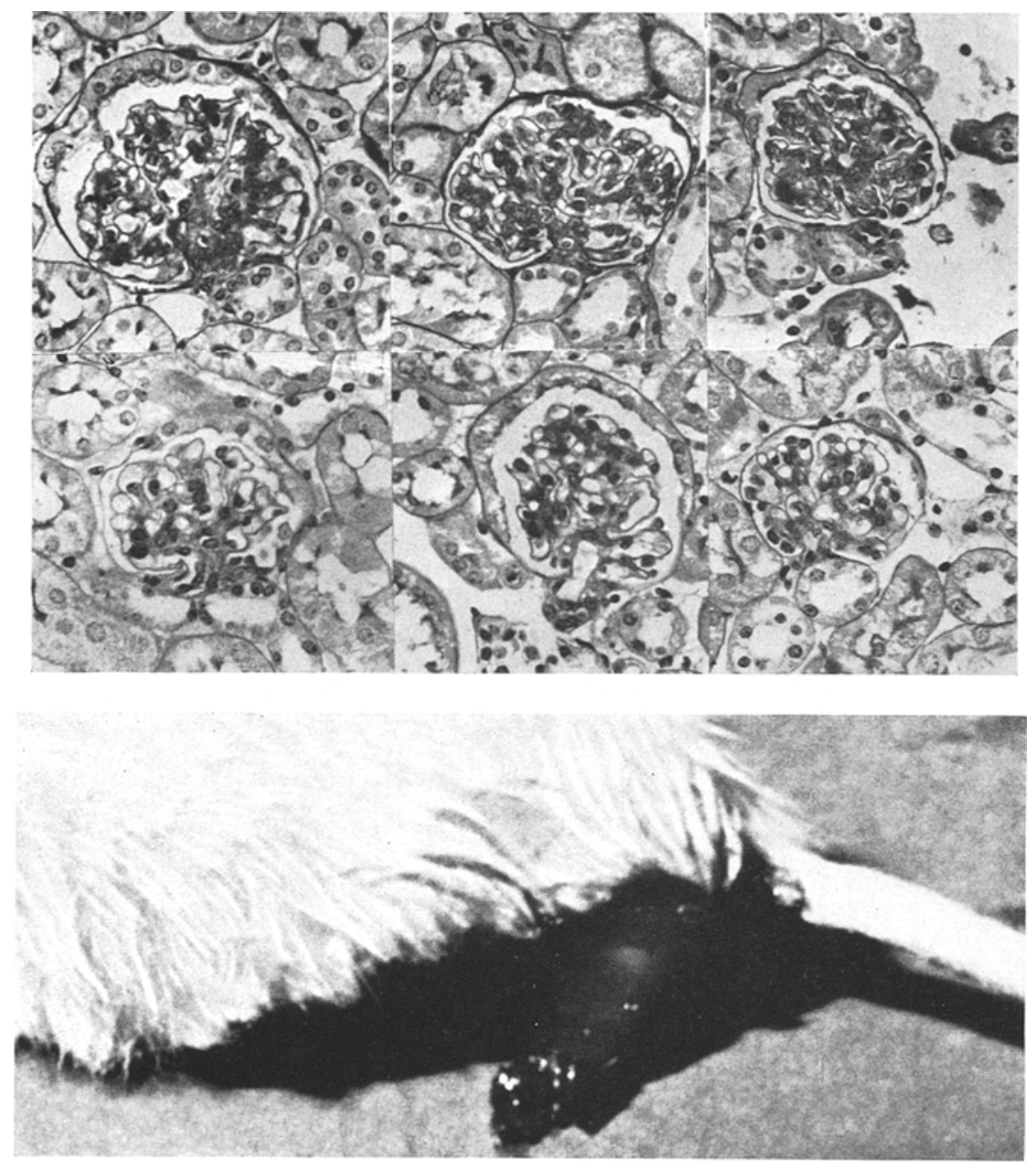

Fig. 6. Top- First biopsy. Bottom-Second biopsy 2 months after the first; increased mesangial matrix and cells, diffusely distributed in $3 \mathrm{KK}$ mice

Fig. 7. Gangrene in the KK mouse

phosphate or both. Fungus stains and virus cultures were negative.

When serum calcium, phosphorous and alkaline phosphatase levels were measured, only the alkaline phosphatase levels were found elevated in the KK group (mean values: 18.5 Bodansky units for the KK, and 10 B.U. for the controls).

Microaneurism in the retina: No microaneurisms were found when the trypsin digestion technique was used". Using a modified in vivo silver nitrate "perfu-

2 Studies done by Dr. T. Best from the Dept. of Ophthalmology, New York Medical College. arteries and arterioles, but no visible occlusion. In two of the three animals extensive calcification in cardiac muscle tissue was noted. Dr. D. L. Coleman found gangrene of the extremities in some nondiabetic mice. (Personal communication)

\section{Discussion}

The significant differences between the mean blood sugar of the two mouse strains, including the fasting

3 In the last few days 1 control was also found with wet gangrene of the extremities. 
stage, plus the abnormal response to several hormones in some animals with normal tolerance to glucose, seems to justify. the diagnosis of diabetes in the KK mouse. The difference in the percentage of hyperglycemic animals in different generations may be explained by a decreased viability of the severely diabetic mice, resulting in mating primarily among almost normoglycemic animals.

Significantly different T.R.I. values were found starting at 4 months. This "delay" (when compared with other species), in showing abnormally high values may be significant in trying to explain the pathogenesis of the diabetic sydrone of the KK mouse.

The glomerular lesions in the KK mice are somewhat different when compared with the human lesions, particularly the presence of cells in nodules and its localization near the hilus rather than at the periphery of the lobule. The absence of vascular lesions in arteries and arterioles is another dissimilarity.

Similarities with human pathology include the presence of lesions in a genetically determined diabetic mouse, particularly after some months of diabetes; diffuse increase in mesangium terminating in severe glomerulosclerosis; the presence of exudative lesions, and the segmental thickening of the basement membrane. The occurrence of some of these glomerular changes in young animals with the glomerulosclerosis and collapse of glomeruli in the older age groups may also be considered as favoring the diabetic origin of these lesions.

The relation of the corneal opacities with the diabetic syndrome is not clear to us at the present time. Finally, the presence of gangrene in the extremities and probably microaneurisms in the retina, seems to suggest that a generalized angiopathy "accompanies", the diabetic syndrome.

\section{References}

1. Kaczurowsky, M. S.: (personal communication).

2. Lemberg, A., Penhos, J.C., Camerini-Davalos, R.A.: Liver lipid content in fetuses at different stages of pregnancy in KK and Swiss Albino mice. To be published.

3. Mittl, R., Galin, M.A., Oppermann, W., CameriniDavalos, R.A., Spiro, D.: Corneal calcification in spontaneously diabetic mice. "Invest. Ophthalmology". Pg. 137, Feb. 1970

4. Nakamura, M., Yamada, K.: Studies on a diabetic (KK) strain of the mouse. Diabetologia 3, 212-221 (1967).

5. Oppermann, W., Methalia, S.D., Sodero, E., Cole, H.S., Camerini-Davalos, R.A.: A sensitive micromethod for the simultaneous determination of insulin and growth hormone by double antibody precipitation. Clin. Bio. Chem. 2, $341-348$ (1969).

6. - Ehrenreich, T., Camerini-Davalos, R.A.: Sequential metabolic and histologic studies in the KK mice. Submitted for publication.

7. Penhos, J.C., Wu, C.H., Camerini-Davalos, R.A.: Effect of several hormones on the tolerance to glucose in the nondiabetic stage of KK mice. J. Exp. Zool. 171, 209-216 (1969).

8. Treser, G., Oppermann, W., Ehrenreich, T., Lange, K., Levine, R., Camerini-Davalos, R.A.: Glomerular lesions in a strain of genetically diabetic mice. J. $\exp$. Biol. 129, 820-823 (1968).

R. A. Camerini - Davalos, M. D. New York Medical College 1149 Fifth Avenue

Now York, N. Y. 10029, USA 